\title{
A low-temperature method for the isolation of small-intestinal epithelium along the crypt-villus axis
}

\author{
Neil FLINT, Frances L. COVE and Gareth S. EVANS \\ Cancer Research Campaign, Department of Epithelial Biology, Paterson Institute for Cancer Research, \\ Christie Hospital and Holt Radium Institute, Wilmslow Road, Withington, Manchester M20 9BX, U.K.
}

\begin{abstract}
A variety of enzymic and non-enzymic methods to isolate epithelium from the small intestine have been previously published. Sequential fractionation of cells from the villus to the crypt has been reported in some of these papers, which allows the comparative study of terminally differentiated and proliferative cell phenotypes. However, these methods often involve the incubation of tissues at $37^{\circ} \mathrm{C}$, which may affect the structural and biochemical integrity of the cells. We have developed a rapid low-temperature $\left(4^{\circ} \mathrm{C}\right)$ method for isolating purified populations of crypt and villus cells from mouse and rat intestines. The fractionated cells have been partially characterized, and the potential value of the procedure has been indicated by the ability to analyse the comparative protein and mRNA expression along the crypt-villus axis.
\end{abstract}

\section{INTRODUCTION}

The epithelium of the small intestine is maintained by a small number of pluripotent stem cells near the base of the crypts of Lieberkühn. These stem cells give rise to progeny, most of which migrate up the crypt-villus axis, undergo functional and morphological differentiation and give rise to the variety of terminally differentiated phenotypes seen on the villus (Potten \& Loeffler, 1987; Trier \& Madara, 1981). This includes the development of well-defined apical microvillar brush borders and the maturation of a number of apical (e.g. alkaline phosphatase) or basolateral (e.g. $\mathrm{Na}^{+} / \mathrm{K}^{+}$-ATPase) enzymes. It is thought that a variety of endogenous factors regulate cellular differentiation; these may include peptide growth factors, hormones, neuropeptides and cell-matrix or cell-cell interactions with the underlying mesenchyme. The need for suitable models in vitro to study the control of proliferation and terminal differentiation is therefore important in understanding the organization of many epithelial tissues. Most previous emphasis has been placed on the development of organ- and cell-culture models (Quaroni \& May, 1980; Trier, 1980); however, these cannot fully recapitulate the complexity of the system in vivo. The spatial organization along the crypt-villus axis has allowed the development of methods to isolate crypt and villus cells as separate fractions from adult tissues. The most notable of these methods was developed by Weiser (1973), who isolated crypt and villus fractions from adultrat intestines by using bivalent-cation-chelating agents at $37^{\circ} \mathrm{C}$. When the isolated cell fractions were analysed for the expression of characteristic brush-border enzymes and the incorporation of $\left[{ }^{3} \mathrm{H}\right]$ thymidine, an apparent gradient of initially terminally differentiated to primitive undifferentiated cells was seen as a function of time (Weiser, 1973). Other non-enzymic methods have also been published, which tend to include variations in the physical handling of the tissues and the chelating solutions used (for review, see Remke et al., 1988). However, in many of these reports little morphological or histological evidence for the apparent gradient of cell types was given.

Physical isolation at $37^{\circ} \mathrm{C}$ may affect some biochemical and molecular processes (e.g. mRNA stability and membrane receptor internalization); we have therefore developed a lowtemperature $\left(4^{\circ} \mathrm{C}\right)$ adaptation of the original method reported by Weiser (1973). This allows the isolation of purified whole crypts or sheets of villus cells within $40 \mathrm{~min}$. The samples obtained have been used to study protein and mRNA expression along the crypt-villus axis, and the potential use of this technique for other studies is discussed.

\section{MATERIALS AND METHODS}

\section{Chemical sources}

Buffer salts, chelating agent, sugars and trichloroacetic acid were obtained from BDH Chemicals, Poole, Dorset, U.K., except for dithiothreitol and D-sorbitol, which were obtained from Sigma Chemical Co., Poole, Dorset, U.K. Hanks' balanced salt solution was supplied by Northumbrian Biologicals, Cramlington, Northumberland, U.K. $\left[\mathrm{Me}^{-}{ }^{3} \mathrm{H}\right]$ Thymidine (sp. radioactivity $247.9 \mathrm{GBq} / \mathrm{mmol}$ ) was obtained from Du Pont (U.K.), Stevenage, Herts., U.K. Ecoscint A was obtained from National Diagnostics, Aylesbury, Bucks., U.K.

\section{Animal tissue sources}

Male outbred Wistar rats (40-60 days old) or BDF1 mice (40-60 days old) were used in all cases throughout the study. The animals were injected intraperitoneally with $\left[{ }^{3} \mathrm{H}\right]$ thymidine $(1 \mu \mathrm{Ci} / \mathrm{g}) 1 \mathrm{~h}$ before the isolation to label the proliferative fraction of the epithelium. After killing by cervical dislocation, the complete small intestine was removed from each animal and flushed with cold Hanks' solution $\left(4^{\circ} \mathrm{C}\right)$ containing $0.5 \mathrm{~mm}$ dithiothreitol to remove the luminal contents. The epithelium was then isolated by a modification of the method described by Weiser (1973).

\section{Isolation of the epithelium from the crypt and villus regions}

The epithelium from the crypt-villus axis was isolated by a modification of the Weiser (1973) method (Scheme 1). The fractions collected were then stored on ice until the end of the isolation, after which they were centrifuged at low speed and the resultant pellet was studied by phase microscopy to assess the relative proportions of crypt and villus epithelium. Samples were then assayed for alkaline phosphatase activity and thymidine incorporation to characterize biochemically the level of proliferative/differentiated phenotypes in the various fractions. Pieces of the intestine were also taken at different stages of the isolation and treated with Carnoy's fixative for histological examination. This method was essentially the same for both rat and mouse; however, longer incubation times and more vigorous shaking was required for the mouse intestine.

In order to determine the effect of isolation at $37^{\circ} \mathrm{C}$ on the integrity of the RNA, a second method, based on that described by Barnard et al. (1989), was performed on the same tissues. Briefly, the method described in Scheme 1 was followed until step 3 , at which point the tissues were divided into five Universal tubes containing $20 \mathrm{ml}$ of chelating buffer. These tubes were 
Step 1

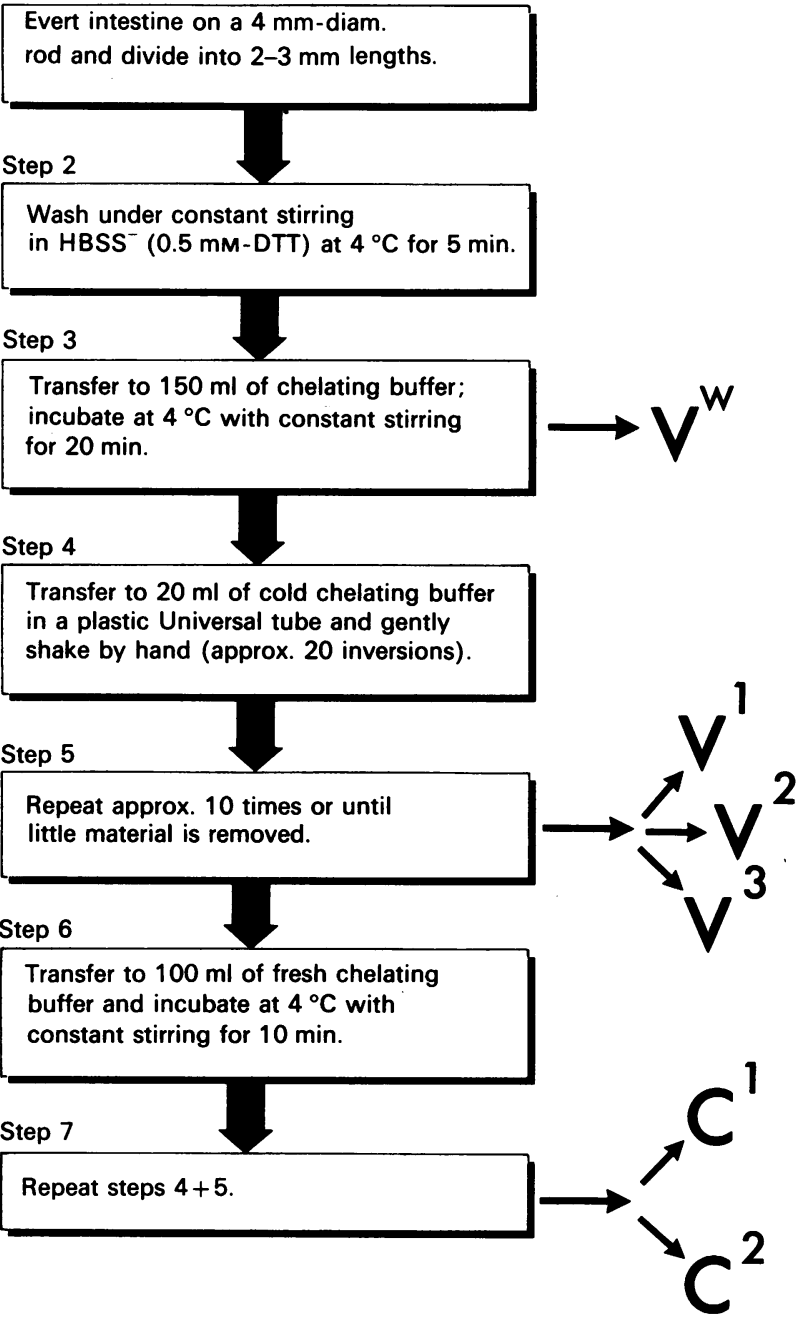

Scheme 1. Schematic flow diagram summarizing the procedure used to isolate intestinal epithelial cells at $4^{\circ} \mathrm{C}$

The constituents of the chelating buffer ( $\mathrm{pH} \mathrm{7.3)}$ were: $27 \mathrm{~mm}$ trisodium citrate, $5 \mathrm{~mm}-\mathrm{Na}_{2} \mathrm{HPO}_{4}, 96 \mathrm{mM}-\mathrm{NaCl}, 8 \mathrm{~mm}-\mathrm{KH}_{2} \mathrm{PO}_{4}$, $1.5 \mathrm{~mm}-\mathrm{KCl}, \quad 0.5 \mathrm{~mm}$-dithiothreitol, $55 \mathrm{~mm}$-D-sorbitol, $44 \mathrm{~mm}$ sucrose. Cells were collected as villus fractions $\mathbf{V}^{\mathbf{w}}$ (material from initial wash), $\mathbf{V}^{\mathbf{1}}$ (first three tubes from repeated shaking by hand in steps 4 and 5), $V^{2}$ (tubes $4-6$ from hand-shaking steps 4 and 5), $V^{3}$ (tubes 7-10 from hand-shaking steps 4 and 5) and crypt fractiuns $C^{1}$ (tubes 1-5 from repeated hand-shaking in step 7), $C^{2}$ (tubes 6-10 from hand-shaking step 7). Abbreviations: DTT, dithiothreitol; HBSS $^{-}$, Hanks' balanced salts solution (low $\mathrm{Ca} / \mathrm{Mg}$ content).

incubated in a shaking water bath at $37^{\circ} \mathrm{C}$, and one tube was removed every $10 \mathrm{~min}$ and then shaken by hand as in Scheme 1 to release epithelial material. This was continued until four fractions had been collected $\left(\mathbf{F}^{\mathbf{1}}-\mathbf{F}^{4}\right)$, after which the final tube was transferred to $20 \mathrm{ml}$ of fresh chelating buffer in a Universal tube and incubated in the shaking water bath for a further 20 min. After the final incubation, the last tube was removed and shaken by hand as previously described $\left(\mathrm{F}^{5}\right)$. All fractions were again stored on ice until the end of the isolation, after which the released material was collected by low-speed centrifugation. Again, an estimate of the proportions of crypt and villus cells in the various fractions was made by observations under phase microscopy and by histological examination of the resulting tissues at various stages in the isolation.

\section{Intestinal-cell characterization}

Differentiated cells released from the villus region of the epithelium were identified by the alkaline phosphatase activity in the cell isolates. The samples were first disrupted by sonication for $5 \mathrm{~s}$ at $10 \mu \mathrm{m}$ wavelength with a MSE Soniprep 150 instrument; the membrane fraction was then enriched by ultracentrifugation at $12000 \mathrm{~g}$ for $5 \mathrm{~min}$. A portion of the suspension was then incubated for $5 \mathrm{~min}$ at room temperature in the enzyme substrate (50 mM-Tris/HCl, $5 \mathrm{~mm}$-p-nitrophenyl phosphate, $5 \mathrm{~mm}-\mathrm{MgCl}_{2}$, $0.25 \mathrm{~mm}-\mathrm{CaCl}_{2}, 0.2 \mathrm{~mm}-\mathrm{MnCl}_{2}, \mathrm{pH} 9.0$ ). The phosphatase activity was then determined by the released $p$-nitrophenol in a microtitre-plate assay by using a Titertek multiscan plate-reader at $414 \mathrm{~nm}$.

The proliferative cells released from the crypt were identified on the basis of $\left[{ }^{3} \mathrm{H}\right]$ thymidine incorporation after a $60 \mathrm{~min}$ pulse (see above). This was measured after precipitation of $200 \mu \mathrm{l}$ portions of the isolated samples with $5 \%$ trichloroacetic acid (to release acid-soluble material). The precipitate was then dissolved in $0.1 \mathrm{M}-\mathrm{NaOH}$, neutralized with an equal volume of $0.1 \mathrm{M}-\mathrm{HCl}$ and added to $10 \mathrm{ml}$ of Ecoscint $A$ scintillation fluid. The radioactivity was then determined by liquid-scintillation counting on a Beckman LS1801 instrument and represented as d.p.m. In both assays, the results were expressed per unit of protein as determined by a micro-titre modification of the Bradford method (Redinbaugh \& Campbell, 1985).

\section{Isolation of mRNA}

Cytosolic RNA was isolated by an enucleation method described by Wilkinson (1988) and agarose-gel electrophoresis was performed as described by Sambrook et al. (1989). The resulting gel was stained in ethidium bromide $(5 \mu \mathrm{g} / \mathrm{ml})$ and the bands were made visible by u.v. to detect any degradation.

\section{Estimation of cellularity}

Owing to the difficulties of making accurate cell counts of clumps of cells (e.g. crypt organoids), an analysis of the DNA with respect to that estimated to be contained in a single rat cell was used to determine total cellularity. Estimations of the cellular content of the isolated fractions were made by pooling $\mathrm{V}^{\mathbf{w}}-\mathrm{V}^{3}$ and $\mathrm{C}^{1}-\mathrm{C}^{2}$ as villus and crypt fractions respectively. The DNA was then extracted by a modification of the method described by Gross-Bellard et al. (1973). The total cellularity was then calculated from an estimate of DNA per cell of $6.5 \mathrm{pg}$.

\section{RESULTS AND DISCUSSION}

Attempts to develop models for the study of the epithelium lining the crypt-villus axis have relied on the isolation of cells at $37^{\circ} \mathrm{C}$. We have now developed a technique by which purified populations of proliferative and terminally differentiated epithelia can be obtained at $4{ }^{\circ} \mathrm{C}$ (Table 1$)$. This method produces initial fractions $\left(\mathrm{V}^{\mathbf{w}}\right)$ of pure villus cells as large sheets of epithelium (Fig. 1a) with distinct brush borders. These cells have been shown to be amitotic, and express the characteristics of terminally differentiated enterocytes found on the villus, but not in the crypts. Fractions removed at the end of the isolation $\left(\mathrm{C}^{2}\right)$ consist of essentially pure suspensions of intact crypt organoids apparent by the classical tubular organization (Fig. 1b). The total cell yield of this method from adult-rat small intestine was also analysed. Approx. $1.7 \times 10^{8}$ crypt cells and $1.5 \times 10^{9}$ villus cells could be isolated per animal at $4^{\circ} \mathrm{C}$, as calculated from the pooled DNA content of the crypt and villus fractions.

The isolation of epithelial cells from the small intestine at $37^{\circ} \mathrm{C}$ resulted in similar proportions of isolated crypt and villus cells, in that $\mathrm{F}^{\mathbf{1}}$ consisted predominantly of villus sheets, $\mathrm{F}^{5}$ was an enriched sample of crypts and $\mathrm{F}^{2}-\mathrm{F}^{4}$ consisted of relatively 
Table 1. Description of the morphological appearance of cells in the fractions isolated by the low-temperature method

\begin{tabular}{|c|c|}
\hline Fraction & Description \\
\hline $\mathrm{V}^{\mathrm{w}}$ & $\begin{array}{l}\text { Large sheets of villus cells with distinct brush-border } \\
\text { margins (Fig. } 1 a \text { ) and very few, if any, contaminating } \\
\text { crypt cells. }\end{array}$ \\
\hline $\mathrm{V}^{1}$ & $\begin{array}{l}\text { Predominantly sheets of villus cells with a small } \\
\text { proportion of intact crypt organoids were removed at this } \\
\text { stage. }\end{array}$ \\
\hline $\mathrm{V}^{2} / \mathrm{V}^{3}$ & $\begin{array}{l}\text { Smaller sheets of villus cells with many small clumps and } \\
\text { single enterocytes were present. The crypt organoids } \\
\text { comprised a larger proportion resulting in an approx. 1:1 } \\
\text { ratio of crypts and villi. }\end{array}$ \\
\hline $\mathrm{C}^{1}$ & $\begin{array}{l}\text { Large numbers of crypt organoids with some small villus } \\
\text { cell aggregates and single cells. }\end{array}$ \\
\hline $\mathrm{C}^{2}$ & $\begin{array}{l}\text { These fractions were essentially pure crypts of intact } \\
\text { tubular morphology (Fig. } 1 b \text { ). At higher magnification, } \\
\text { distinct Paneth cells were visible at the base of the } \\
\text { organoids. }\end{array}$ \\
\hline
\end{tabular}

equal proportions of both cell types. However, in contrast with the low-temperature isolation, the initial fraction of villus cells which were present as small sheets at $37^{\circ} \mathrm{C}$ dissociated rapidly in later fractions. This rapid dissociation also affected the isolated crypt organoids; indeed, in $\mathbf{F}^{5}$, although enriched in crypts, many of the organoid structures had been reduced to clumps of cells.

Therefore, the major advantage of isolation at low temperature appears to be that we can prevent possible deleterious effects which occur at $37^{\circ} \mathrm{C}$ owing to compromised cellular adhesion and membrane integrity. This may include internalization of surface receptors, which has been observed for insulin and epidermal-grow-factor receptors in isolated intestinal cells within $60 \mathrm{~min}$ at $37^{\circ} \mathrm{C}$ (Gallo-Payet \& Hugon, 1984, 1985). The loss of

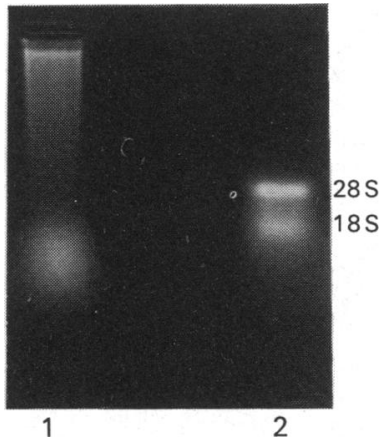

Fig. 2. Comparison of mRNA from cells isolated at $4^{\circ} \mathrm{C}$ and $37^{\circ} \mathrm{C}$ by agarose-gel electrophoresis

Lane 1, crypt sample isolated at $37^{\circ} \mathrm{C}$ showing degradation of the RNA. Some high-molecular-mass contamination is also evident, which may be degraded DNA released into the cytosol. Lane 2, crypt sample isolated at $4{ }^{\circ} \mathrm{C}$ showing distinct $18 \mathrm{~S}$ and $28 \mathrm{~S}$ subunits.

relatively unstable mRNA transcripts or their protein products may also be prevented by lower temperature (Weiser et al., 1987). With this in mind, we decided to compare extracted mRNA from cells isolated by a previously described $37^{\circ} \mathrm{C}$ method (Barnard et al., 1989) and by the low-temperature method reported here. After separation on agarose gels, significant degradation of the RNA was observed at $37^{\circ} \mathrm{C}$; however distinct ribosomal subunits were seen in the RNA from low-temperature isolates (Fig. 2). In addition, high-molecularmass contamination was also seen in material isolated at $37^{\circ} \mathrm{C}$, which may indicate a deterioration in nuclear integrity and the subsequent release of DNA into the cytosol. Indeed, nuclear pyknosis was evident in epithelium isolated at higher temperatures. Further evidence for the stability of the cellular isolates at low temperature was found by the fact that isolated RNA was suitable for Northern-blot analysis (L. Heather, un-
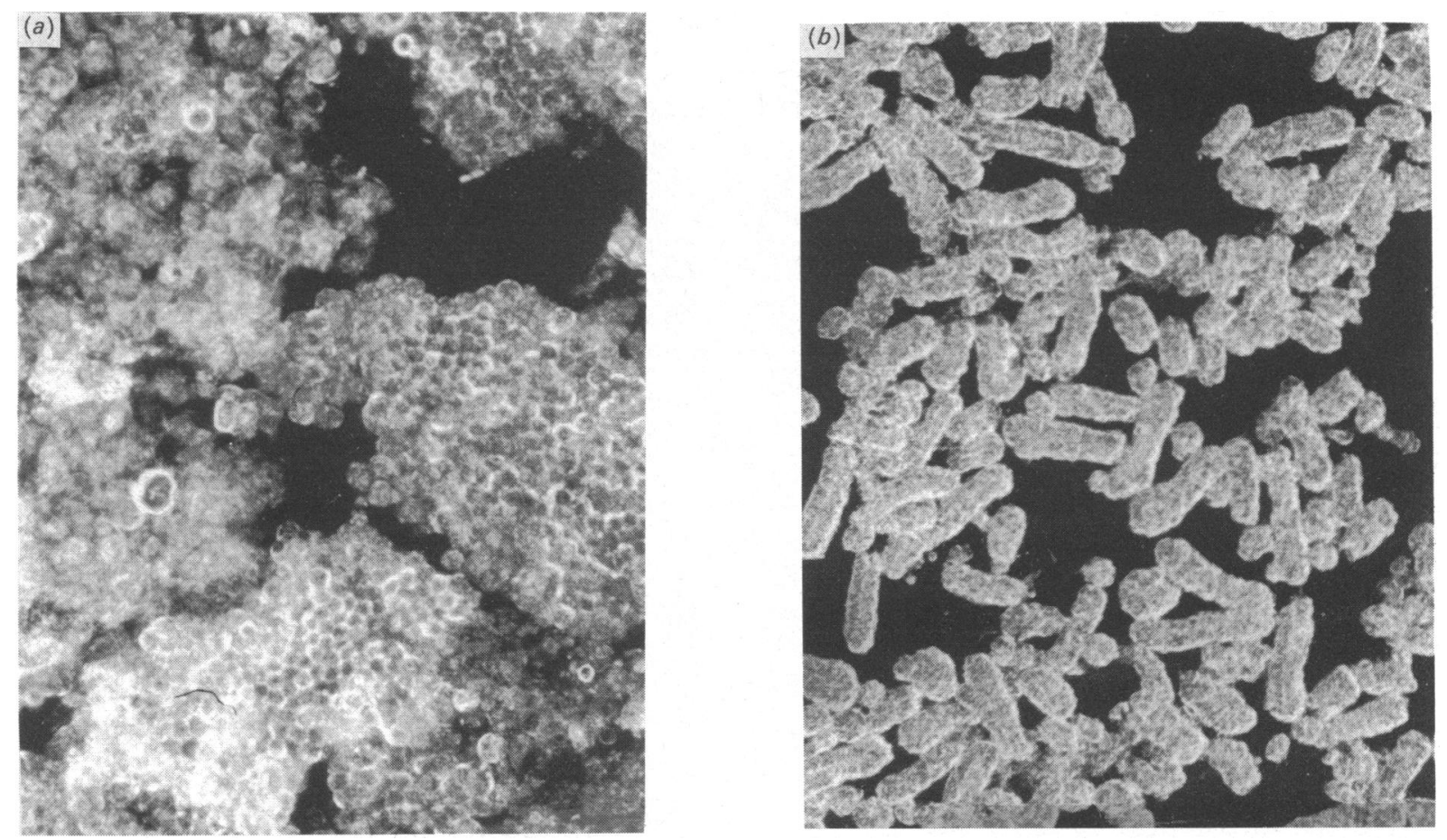

Fig. 1. (a) Isolated villus cells from fraction $\mathrm{V}^{\mathrm{w}}$ clearly seen as large sheets of polygonally arranged cells under dark-field microscopy (magnification $\times 130$ ); (b) isolated crypts from fraction $\mathrm{C}^{2}$, showing the purity of the crypt suspension under dark-field microscopy (magnification $\times 80$ ) 


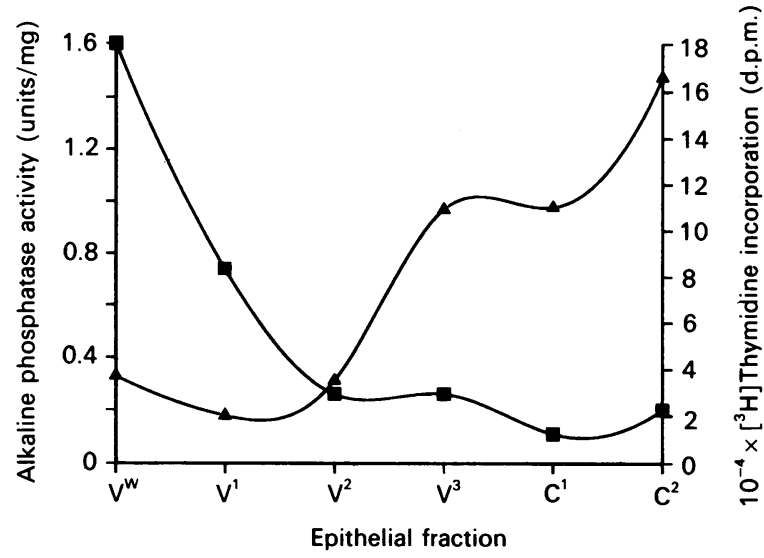

Fig. 3. Levels of thymidine incorporation $(\Delta)$ and alkaline phosphatase activity $(\square)$ in the cell fractions isolated by the low-temperature method (see Table 1)

published work). Another advantage of low-temperature isolation is the retention of structural integrity, not only in the morphology of the individual cells (i.e. sharply defined columnar shape), but also of the functional epithelium. The ability to remove large sheets of villus cells and crypt organoids with intact junctional complexes may allow their use in possible functional studies.

The study of alkaline phosphatase expression and thymidine incorporation by cells isolated at $4{ }^{\circ} \mathrm{C}$ also revealed a gradient of activity/incorporation similar to those previously reported (Fig. 3). However, the morphological evidence suggests that this is not due to a sequential isolation from villus tip to crypt base, but is a result of changing proportions of crypt and villus cells throughout the fractions. The gradients obtained by other methods may also be due to high activity in a pure suspension of cells which is gradually diluted out by increasing numbers of non-expressing cells. Morphological evidence suggests that this is the case for the $37^{\circ} \mathrm{C}$ isolation method that we used.

As reported, fractionated cells obtained by the low-temperature method have proved suitable for studies of mRNA ex- pression and possible changes associated with the onset of terminal differentiation. Other comparative studies which have been carried out include the changes in expression of cytokeratin polypeptides in the crypt-villus axis (N. Flint \& G. S. Evans, unpublished work) and the synthesis of stress proteins after cytotoxic insult ( $\mathrm{N}$. Thakker, personal communication). The maintenance of cell and tissue morphological integrity may also provide models for biochemical studies of gene expression and receptor analysis along the crypt-villus axis. However, when attempts were made to grow these cells in culture, they were found to be unable to proliferate in vitro. It should also be noted that this method was developed for rat/mouse intestine of defined ages, and therefore application to other species or ages may require some initial adaptations before successful isolation is achieved.

We thank Lisa Heather for the Northern-blot analysis of lowtemperature isolates and Nalin Thakker for the information on stress protein synthesis. This work was supported by the Cancer Research Campaign.

\section{REFERENCES}

Barnard, J. A., Beauchamp, R. D. \& Coffey, R. J. (1989) Proc. Natl. Acad. Sci. U.S.A. 86, 1578-1582

Gallo-Payet, N. \& Hugon, J. S. (1984) Endocrinology (Baltimore) 114, 1885-1892

Gallo-Payet, N. \& Hugon, J. S. (1985) Endocrinology (Baltimore) 116, 194-201

Gross-Bellard, M., Oudet, P. \& Chambon, P. (1973) Eur. J. Biochem. 36, 32-38

Potten, C. S. \& Loeffler, M. (1987) J. Theor. Biol. 127, 381-391

Quaroni, A. \& May, R. S. (1980) Methods Cell Biol. 21B, 403-427

Redinbaugh, M. G. \& Campbell, W. H. (1985) Anal. Biochem. 147, $144-147$

Remke, H., Repin, V. S. \& Sviridov, D. D. (1988) Exp. Pathol. 35, 1-23

Sambrook, J., Fritsch, E. F. \& Maniatis, T. (1989) Molecular Cloning, a Laboratory Manual, 2nd edn., pp. 7.12-7.15, Cold Spring Harbor Laboratory, Cold Spring Harbor, NY

Trier, J. S. (1980) Methods Cell Biol. 21B, 365-384

Trier, J. S. \& Madara, J. L. (1981) in Physiology of the Gastrointestinal Tract (Johnson, L. R., ed.), pp. 925-961, Raven Press, New York

Weiser, M. M. (1973) J. Biol. Chem. 248, 2536-2541

Weiser, M. M., Sykes, D. E. \& Killen, P. D. (1987) Trans. Assoc. Am. Physicians 100, 316-328

Wilkinson, M. (1988) Nucleic Acids Res. 16, 10933

Received 23 April 1991/21 June 1991; accepted 11 July 1991 